water bivalves of our rivers and lakes. Shells and pearls of Unio, Anodon, Margaritana, etc., of many species and varied tints, are here brought together, and form a very interesting exhibit of the yield of these beautiful objects by the "river mussels" so abundart in the United States.

April 15, 1889.

Stated Meeting.

The President, Dr. Newberry, in the chair.

Fifty persons present.

The fifth lecture of the Public Course was delivered, upon

GLACIAL MORAINES IN THE FRONT RANGE, COLORADO, by Mr. Frederick H. Chapin, of Hartford, Conn.

[Illustrated with an extensire series of lantern views taken by the lecturer during his travels among the mountains referred to.]

Dr. NRWBERRY added some remarks in regard to the eroding power of ice, as shown in the great moraines observed by him in British America.

A unanimous vote of thanks was tendered to Mr. CHA PIN.

April 22, 1889.

Stated Meeting.

The President, Dr. NewberRy, in the chair.

Twenty-one persons present.

Dr. J. J. Friedrich exhibited a number of specimens from the shell-mounds of Cedar Keys, Florida, consisting chiefly of shells. He had been unable to find a trace of implements, un- 
less a piece broken apparently from the lip of a large conch, and of uncertain use, could be so regarded. This mound was found to be very extensive; and he would estimate the time required for its construction as perhaps four hundred years, - - supposing the population of the islet to have amounted to two thousand. Some of the shells of which it is composed are still abundant on the coast, while others are now rarer, and one species at least has undoubtedly become extinct.

Dr. Newberry said that he also had examined this mound, when on a visit to Florida some years previous. He observed a large live-oak tree growing upon it, indicating of course that a long period had elapsed since the mound had been abandoned and ceased to receive additions. Dr. Friedrich's computation of four hundred years, for the time taken to form the mound, was a minimum period. It was probably much longer, as the population of the islet conld scarcely have been at any time so large as two thousand. He had succeeded in finding a human skull in the mound, and part of a skeleton.

Mr. JoHn C. Henderson read the paper announced for the evening, entitled

\section{THE TEHUANTEPEC SHIP RAILWAY.}

Conterminous for fourteen hundred or more miles with the southern border of the United States, lies the Republic of Mexico, -a country with an area about sixteen times that of the great State of New York.

South of Mexico for about twelve hundred miles, extends a beautiful and fertile region, whose width varies from about three hundred to about twenty-eight miles. This picturesque land may be viewed as a great causeway, uniting North and South America, and dividing, in the middle of the American continent, the waters of the Atlantic Ocean from the Pacific main. Its superb scenery is diversified by a chain of mountains extending almost its entire length and having peaks which rise from three thousand to fourteen thousand feet above the waters of the oceans. From a geographical point of view, the great isthmus which unites the two Americas should be considered as embracing a part of Mexico and as being about fourteen or fifteen hundred miles in length. Its area is about three hundred thousand square miles, -an area out of which six States of the size of New York could be formed. This isthmus is a vast natural bridge,- 
destined to be of priceless value to the people of America,-over which a great railway is some time to be built, which will unite the railway systems of North and South America. Happily, without altering its character as a bridge uniting the northern and southern continents, interoceanic highways for ships can be built across it.

The part of the American isthmus which belongs to Mexico js called Tehuantepec. In the year 1847, the President of the United States offered to make with Mexico a treaty by which our Government would pay fifteen millions of dollars for Teliuantepec. Fifteen millions of dollars, at that time, represented to the Government of the United States a vastly greater sum than it does at the present day. But a far-sighted statesmanship justly lecognized this as a geographical position of great value to the people of North America.

After expensive surveys, it was discovered that however great would be the distance saved by vessels of the United States engaged in coastwise and foreign trade, could they be borne across the northern part of the American isthmus instead of having to make an immense detour of the entire continent,-or to sail many hundreds of miles sonthwardly to enable them to cross the isthmus at Panama or at Nicaragua,-a ship canal at Tehuantepec would have to be constructed over an elevation of between seven and eight hundred feet above the sea, and would require between one and two hundred locks, - in short, that its construction might be justly considered as almost or quite impracticable. But the late Captain James B. Eads raised the question whether science is not equal to devising a better means of transit for ocean vessels across the American isthmus than the best of canal navigation could afford.

One peculiarity believed by many travellers to characterize the orjental nations, is that the people, for generation after generation, use only the same mechanical contrivances that were employed by their fathers. For many hundreds of years canals have been used as highways for commerce in different parts of the world; and these were found, for certain purposes, an improvement upon roads. The famous canals of China have done much to bind together many of its widely separated sections of country, and long before America was discovered by Columbus they might well have filled Europeans with admiration. Many people may be surprised to hear that the freight-boats which are constantly plying upon the rivers and artificial water-courses of China, are so great in number, and her inland commerce of such stupendous dimensions, that it has been said to have a greater amount of tonnage than all the other nations of the earth combined. The canal-system of China, however, is in various respects 
far from perfect, and a railroad system would be an invaluable blessing to the Chinese Empire. But probably vast numbers of Chinese would listen with incredulity should they be told of rail ways which accomplish for commerce far more than canals,indeed, of railroad cars in America upon which Chinese canalboats could be borne with wondrons speed over immense distances.

James B. Eads, one of the most distinguished engineers of his age, devised a railway over which the largest ships in the world are to be transported across the American isthmus at 'Tehuantepec. The railway is to have what may be called heary rails of fine steel. 'The number of rails may be four, or six, or even eight, according to the size of the ship to be transported. At each end of the ship-railway, vessels ure to be conducted into a basin which will open into what may be called a dry-dock, such as is used in raising out of the water the largest ships. As a vessel is raised out of the water, it finds itself on a great car which was waiting at the bottom of the dry-dock to receive it-a great car on wheels and on a railroad. By mechanical contrivances based on very interesting scientific principles, the ship is laid in its cradle as gently, one may almost be permitted to say, as a mother lays her babe upon its little bed. 'The railway car is to have a large number-some hundreds-of wheels, and is to be so admirably constructed of steel that it will possess very great strength. 'The ship when on the car is, by what may well be called a masterpiece of ingenuity, to rest on supports which will so adjust themselves to it that the vessel will be practically as truly water-borne as though it rested on a lake, the weight of the vessel being equally distributed over the entire car. The car, which is to be several hundred feet long, can be lengthened or shortened according to the size of the vessel which it is to transport. The car-wheels are to be two feet in diameter, and are to be placed three feet apart on the six or more rails on which the ship car is to run. 'The question may be raised, "Would not a loaded ship,-which would weigh far more heavily in its centre than at its bow or stern,- when placed on a car, be of such enormous weight that the ground would yield under the crushing pressure which the rails would be called upon to bear?" Eads, when dealing with such a question, showed that a ressel upon the shipcar would have its weight, by the agency of its cradle and the construction of the car, so equalized and distributed over a large surface that no one of the wheels of the car will have to bear a weight greater than five tons, although each of them would be capable of sustaining twenty tons. Orer each wheel will be placed a steel spring capable of bearing twenty tons before closing, $-\mathbf{a}$ 
spring which will make each wheel bear its fair proportion of weight, should it pass over any ordinary inequality in the rails.

'The ship-railway is to have practically no curves. By means of great deflecting-tables the direction of the ship-car whenever necessary is to be turned. 'The lay of the ground at Tehuantepec is very happily suited for such a great railroad. The ship can be borne across the isthmus at the rate of about eight or ten miles an hour or more. Ships using this railway would not only travel across the isthmus much faster than they could by means of a canal, but they would in various respects be safer on the railroad car. A vessel passing through a canal has to move very slowly; it is always in danger of being injured by going a little too close to the side of the canal, and may even at times ground under very unpleasant circumstances.

'There are various reasons why a ship-railway located at Tehuantepec will be of great value to the commerce of the United States. It will be within a few hundred miles of the city of Mexico. It can easily be united to the railroad system of North America. Its commercial relations with the United States and Mexico will necessarily be peculiarly intimate. Eads planned to make a very fine harbor for 'Tehuantepec, which would become an entrepôt for a vast commerce with Mexico, and where vessels could readily be supplied with an abundance of coal from the United States.

To appreciate even faintly the value of a ship-railway at this point, one needs to glance at a map of the American continent and then to extend his view to the map of the world. The American continent is the greatest in length of any continent on the globe. A vessel going from New York to San Francisco cannot sail around the northern part of America, through the icy regions of the Arctic Ocean; while to go around its cold and stormy southern extremity, at Cape Horn, necessitates the sailing of 14,200 nautical miles, - a nautical mile being about onesixth greater in length than is a statute mile. A ship-railway at Tehuantepec would shorten this distance by 9,800 miles, making the voyage but 4,400 miles.

One might here pause and consider how inestimably important to nations is commerce-how it affects the comfort, the wealth, the intellectual tone, and the manners of a people. It is a means of binding together in happy relations widely separated countries. Many an humble workman living in the city of New York has upon his breakfast-table tea which has been transported nineteen or more thousand miles from China, sugar which was obtained from sugar-cane which grew in Cuba or in India, and fruits that were raised in climates suited to their growth. Perhaps the bread which he eats was made of wheat raised on 
the western coast of the United States and has been transported in ships by a long, dangerous voyage around Cape Horn,-the "Cape of Storms," as it has been called.

To say that a people have little commerce is to say that they are devoid of many of the decencies and comforts-and of some of the greatest blessings-of modern civilization. Well may statesmen endeavor to promote the best interests of a people by duly caring for their commercial development.

The Government of the United States has spent, in one form and another, a large amount of money in surveys for a suitable place for a passage across the American isthmus. A practicable route for an interoceanic canal, with locks, at Panama was surveyed by officers of our Government during the administration of President Grant. Had De Lesseps adopted that route, there would have been a canal to-day at Panama. It has been found by surveys that an interoceanic canal could be built at Nicaragua. Gen. Grant refused an offer, made to him by De Lesseps, of fifty or sixty thousand dollars a year to act as President of the Panama Canal Company; but he would gladly, -indeed, it was a noble ambition of his to do so,-have become the President of an interoceanic canal at Nicaragua. The building of such a canal at Nicaragua has much in some respects to commend it to American citizens; but grave doubts were entertained by Captain Eads, -one of the highest of authorities on such a subject,whether it would be practicable to make a suitable harbor at the eastern terminus of the canal. In his opinion, a ship-railway at Tehuantepec would be far better for the people of the United States,-owing to important political as well as commercial reasons, - than would be even an American interoceanic canal at Nicaragua.

As the Anerican isthmus is about 1,500 miles in length, it must make an important difference to the people of North America,and indeed to no inconsiderable degree to England,-whether a gateway for ships across the isthmus is opened at its northern or at its southern part. A vessel going from New York to San Francisco would save about 1,173 miles by going by way of Tehuantepec instead of by way of Panama. On every round trip it would save 2,346 miles.

A large number of the vessels of the United States are propelled by sails. A sailing-vessel going from any American port, and using the ship-railway at Tehuantepec, would enjoy the great advantage of being borne onwards on its journey by friendly trade-winds. To a less extent it would also have this advantage if it went by way of the splendid Lake of Nicaragua. But there is a region of calms in the Caribbean Sea and on the Pacific Ocean off the coast of Panama. Vessels crossing the isthmus 
there would have to go through these calms. The mariner who attempts to cross this region in a sailing-vessel, is, as a rule, subjected to heart-sickening detention. His vessel is apt to lie for day after day and week after week,-and sometimes for month after month,-listlessly on the glassy waters. If the sails fill with wind, and his heart begins to beat with joy, he is very apt to find that only a momentary breeze has swept by, or that a squall ushering in a tropical shower threatens his vessel with destruction. When the sun shines, it does so with a heat so scorching as to injure in various ways the vessel and to make the sailors prematurely old. As the sailor finds that day after day he makes scarcely any progress, he is apt to feel that he would far rather face the storns, and sail 10,000 miles to round Cape Horr, than have his life wasted in a region of calms. But few sailing-vessels would probably attempt a second time to go from New York to the Pacific Ocean by way of Panama. Skilful navigators might indeed get through the region of calms in but one or two weeks' longer time than it would usually take for them to go by way of Nicaragua, - that is, if they knew just how to keep on the borders of the region of calms, or just what course at all times to take; -but on every round trip a sailing-vessel, under the most favorable circumstances that it could expect, would lose much time. Tehuantepec is several hundred miles further north of Nicaragua than is Nicaragua north of Panama. Vessels crossing the isthmus by way of Tehuantepec would often have a breeze when vessels going by way of Nicaragua would meet with no friendly wind. If two sailing-vessels should start from New York or from New Orleans, for almost any port of Asia or Australia, one of them going by way of Tehuantepec and the other by way of Panama, as a rule the one going by way of Tehuantepec would be thousands of miles on its journey,-perhaps at the Sandwich Islands, if its course lay in their direction,- while the other would be lingering in the region of calms.

While a wooden sailing-vessel is lying becalmed off the coast of Panama it is attacked beneath its water-line by what are called ship-worms. The species of ship-worm known as the Teredo navalis is now to be found probably in every sea. These creatures did such injury to the piles which were used on the great dikes that protect Holland from the ocean,- dikes which have cost not less than $\$ 1,500,000$, - that the Dutch Government has at times appealed to science to deliver them from their attacks. These ship-worms, when very young, attack wooden vessels that are not covered with copper sheathing, or in some such way protected from them. The holes by which they enter the sides of a ship are no larger than pins' heads, but when they have once entered the wood they grow rapidly. They line their bores with 
a kind of shelly deposit, and they bore onward as they increase in size. The ordinary Teredo navalis does not grow to be very large, but in the waters off the coasts of the American isthmus ship-worms become sometimes ten inches or even much more in length. Many a gallant vessel has been obliged to succumb to these creatures, the hull becoming honeycombed with the holes which they have bored. It has been supposed that if ships could go suddenly from salt water into fresh water, or lie at anchor in a large fresh-water lake,-such as Lake Nicaragua,- they would be delivered from these pests; but the dreaded Tereclo has been found in brackish water, and one distinguished naturalist has claimed that it has been found alive even in fresh water. But conld a vessel be taken out of the water,-as when it is being transported across the isthmus of 'lehnantepec,-it is almost certain that the ship-worms would quickly die, as they are so sensitive to air that they never attack piers or vessels above the water-line.

Another foe to ships, - of iron as well as of wood,-is the little crustacean shell-fish commonly known as the barnacle. These fasten themselves in such numbers on a vessel that its speed becomes much affected. Fast steamers, -even the finest which sail the seas,-must be taken out of the water from time to time, to rid them of these pests. The barnacles, it is believed, could not live if a vessel could enter fresh water, or lie at anchor in a lake; but though the barnacles would die, their shells would be so cemented to the vessel that it would be needful for the hull to be taken out of the water and scraped. Eads, in planning his ship-railway, made provision for side-tracks upon which the ship-car can be run while the ship with which it is loaded is scraped and painted, and refitted in every way.

Tehuantepec is some six or seven hundred miles nearer to the United States by land than is Nicaragua. By looking at a map it can be seen that, while Panama and Nicaragua are bathed by the waters of the Caribbean Sea, Tehuantepec is washed by the waters of the almost land-inclosed Gulf of Mexico. This great American gulf is about one thousand miles in length by eight hundred in width, and receives the discharge of a vaster river system than is found on any other continent. In to it empties the Mississippi, which, with its forty-two navigable tributaries, waters in part twenty-one States and 'lerritories. Fourteen of these are sometimes called "Mississippi Valley States." This vast, fair, and fertile region is capable of supporting hundreds of millions of people. Joined,- -or to be joined,-with the Mississippi River by a canal, and possibly by a railway for vessels, are the great American lakes,-inland seas, - which have been estimated to contain about one-third of all the fresh water in 
the world. As in some part of the Mississippi valley almost any climate can be found, the most varied products are always being borne in a very economical manner on its waters.

For a long time the Mississippi River was closed to large vessels, owing to a bar at its entrance. Captain Eads rendered his country an inestimable service by devising a method of making a permanent channel at the entrance of the Mississippi-a channel of sufficient size to admit the largest vessels used in commerce. Although thus, and in various ways, Eads had performed services of very great value already to his country, yet he further aspired to the practical opening, for the immense commerce borne on the waters of the Mississippi, by means of a ship railway at Tehuantepec, of a channel into the waters of the Pacific Ocean, which covers nearly two-fifths of the surface of the globe, and waters the shores of continents and islands where live six or seven hundred millions of people. By a map of the Gulf of Mexico it will be seen that 'lehuantepec is opposite to the point where the Mississippi River enters the Gulf. A vessel, when it sails from San Francisco to the mouth of the Mississippi, and goes around Cape Horn, has to travel about 16,112 statute miles, - a much greater distance than it would have to go if it went to Asia or to Australia. Should it be transported across the isthmus at Panama, it would have to sail 5,418 miles, while at Tehuantepec it would need to travel only 3,561 miles,-a less distance by 1,857 miles. By this route it would save on every round trip a distance of 3,714 miles, as compared with Panama. When one reflects how large a commerce might be carried on between the mouth of the Mississippi River and the western coast of the United States, he may well feel that it is a matter of vast importance to our people that the place of transit across the isthmus should be at Tehuantepec rather than at Panama. It would be worth many millions of dollars yearly to the great coastwise trade of the United States to be enabled to cross the isthmus at the former point rather than the latter.

Eads, in planning a ship-railway to cross at Tehuantepec, had in view considerations of a military as well as of a commercial nature. During the great civil war in the United States, he had given much thought to some important military needs of his country. Three days after the flag had been fired upon at Fort Sumter, he had been summoned to Washington by a member of $\mathrm{Mr}$. Lincoln's Cabinet to advise the Government respecting the wisest manner of utilizing for military purposes the Mississippi and other rivers. The great engineer himself at once built with wonderful despatch eight river gunboats. Shortly after presenting these formidable vessels to his Government, he had six more constructed, four of them being built in part on plans 
which he himself devised. The military services which he was enabled to render his country were very great. With his trained eye, Eads saw that, should the United States become engaged in war with a European power, the latter might endeavor to do the United States great injury by seizing and using to its own advantage a ship-canal. He feared that it would be very difficult for our Government to protect against great hostile fleets an interoceanic canal at Panama or at Nicaragua. Such a canal could be very easily rendered useless for long periods in a time of war. A single torpedo would be enough to destroy a lock, and to let loose a flood of water which might greatly injure the canal. A single vessel intentionally sunk in a canal might make it impassable for a fleet of war-ships. Damage done to a shiprailway conld be more quickly repaired. Eads had plans by which the Gulf of Mexico would be practically converted into an American lake. By defending its entrance he would defend Tehuantepec. He devised a plan for the defence of the shiprailway which would practically make it secure against attack by any fleet likely to attempt its capture. It was also to be in such close connection with the railway system of Mexico and of the United States, that large bodies of soldiers could be sent to its defence at very short notice.

On the eastern side, the approach to the ship-railway is to be for twenty-five miles by the beautiful Coatzacoalcos River. On the Pacific side, it will be through a large lagoon. The length of the railway was to be about one hundred and thirty-four miles.

Captain Eads had the pleasure of seeing his plans for a shiprailway at 'Tehuantepec approved by eminent engineers. Constructors-in-chief, alike of the British and of the American navy, as well as eminent builders of ships and of dry-docks in Great Britain, united in giving their indorsement in an official manner to the practicability of transporting ships across the American isthmus by means of Eads' ship-railway. A committee of the United States Senate, after listening to whatever objections the adrocates of an interoceanic canal had to offer to Eads' plan, made a report on March 6th, 1882, in the course of which it was said: "The first question the committee considered was as to the practicability of constructing a railway for the purpose of transporting ships and their cargoes. The testimony before the committee conclusively demonstrates the fact that such a railway is entirely practicable, and that loaded vessels can be transported over the same with absolute sufety and economy." In the course of this report, the committee, after quoting from testimony given by American engineers respecting the practicability of constructing a ship-railway, continued: 
"The testimony on this subject is so overwhelming and conclusive in its character that the committee has no hesitation in reporting that the construction of a ship-railway and its successful operation are entirely practicable." The Senate committee, after quoting at considerable length from a very interesting report that a Congressional committee had already made on the subject, - a report which especially pointed out the immense advantages which the people of the United States would derive should the gateway across the isthmus be at 'Tehuantepec rather than at Nicaragua or Panama,-added the following statement: "The committee has considered the testimony taken before the House committee, and fully indorse the statement that Tehuantepec is the American route, and that the transit-way shonld by all means be located there in preference to any other point upon the isthmus."

In connection with the Senate report just quoted, it is interesting to observe that President Cleveland, in his Annual Message dated December 8th, 1885, alluding to Eads' ship-railway, somewhat incidentally said: "The Tehuantepec route is declared, by engineers of the highest repute and by competent scientists, to afford an entirely practicable transit for vessels and cargoes, by means of a ship-railway from the Atlantic to the $\mathrm{Pa}$ cific." Such a statement, which had been made by a committee of Congress, must have been very gratifying to Eads.

Captain Eads wished the United States Government, as well as the Government of Mexico, to aid in the construction of the ship-railway by guaranteeing a limited amount of interest on the money spent in construction. This money, however, was to be but practically a loan. The Government of the United States was to receive in various ways very valuable concessions from the railway company. One important feature of Eads' project was that the United States Government was not to pay any money in aiding the ship-railway company, unless the latter should successfully carry out its contract to transport over the railway in a specified manner vessels of a given tonnage. Unless the ship-railway accomplished all that it agreed to do, it was to receive no aid from our Government.

It was not given to Eads to see his great project in active operation. Some of us, let us hope, will live to have that pleasure. Eads' ship-railway is designed to transport in a day a far larger number of vessels than can an interoceanic canal. It can be built much more rapidly than a canal. It can afford, it is believed, to trunsport vessels at less cost than is possible by canal navigation. If successful, it will be a means of greatly increasing the inducements to Americans to build ships, and will in various ways call into life many new industries. The people of 
the United States would not wish to see it controlled by a foreign power. They would not wish to see it becoming a great monopoly, charging exorbitantly for transporting American vessels from ocean to ocean. Probably in no juster or better way could the Government of the United States have a voice in its management, than by duly aiding in its construction. It may be worth every year to the people of the United States far more than will be its entire cost,- - eren though that cost should be fifty or one hundred millions of dollars. It will pass over a country having, except near the Coatzacoalcos River, a very healthy climate. At eitner end of the ship-railway, a great commercial city may be expected to arise; and the Mexican Government is deeply interested in securing its construction. We may hope that it will soon be built.

Remarks on Mr. Henderson's paper were made by Mr. ANDrEws, who sustained the views therein set forth.

April 29, 1889.

Owing to the celebration of the Centennial of Washington's Inauguration, during this and the following day, no meeting of the Academy was held on this evening.

May 6, 1889.

Regular Business Meeting.

The President, Dr. NewBerry, in the chair.

Twenty-three persons present.

The Report of the Council was read, and its several recommendations adopted, viz.:

(1) The election of the following gentlemen as Resident Members:-

$$
\begin{aligned}
& \text { Orlando B. Potter. } \\
& \text { Emory McClintock. }
\end{aligned}
$$

(2) The election of the following Resident Members as Fellows: 